\title{
Toxicity and Reproductive Parameters Impairment of Cypermethrin in Male Guinea Pig (Cavia porcellus)
}

\author{
Bertin Narcisse Vemo ${ }^{1 *}$, Augustave Kenfack ${ }^{1}$, Ferdinand Ngoula ${ }^{1}$, Edouard Akono Nantia ${ }^{2}$, \\ Claude Cedric Njieudeu Ngaleu ${ }^{1}$, Arthénice Jemima Nounamo Guiekep ${ }^{1}$, \\ Astride Martine Megnimeza Tsambou ${ }^{1}$, Ferry Nana Yidjeu ${ }^{1}$, Chancel Patrick Nelo ${ }^{1}$, Alexis Teguia ${ }^{1}$
}

${ }^{1}$ Department of Animal Sciences, Faculty of Agronomy and Agricultural Sciences, University of Dschang, Po Box 188 Dschang-Cameroon. ${ }^{2}$ Department of Biochemistry, Faculty of Sciences, University of Bamenda, Po Box 39, Bambili, Cameroon.

\section{A R T I C LE IN F O}

\section{Research Article}

Received 06 July 2017

Accepted 22 November 2017

Keywords:

Cypermethrin

Male guinea pig

Reproduction impairment

Testosterone

Toxicity

${ }^{*}$ Corresponding Author:
E-mail: vemobertin@yahoo.fr

\begin{abstract}
A B S T R A C T
Cypermethrin is a large spectrum action insecticide, globally employed to control pests in agriculture and some human and domestic animals ectoparasites. This study aimed to evaluate its toxicity and reproduction impairment in male guinea pig. Forty adult male guinea pigs were divided into 4 groups and orally submitted to $0,92,137.5$ and 275 $\mathrm{mg} / \mathrm{kg}$ body weight/day for 90 days. The weight of the liver increased significantly, while that of kidneys decreased significantly in treated animals compared to controls. Serum concentrations of creatinine, urea, ALAT, ASAT, total cholesterol, prostatic acid phosphatase increased significantly, while the testicular total protein level decreased significantly in groups given the insecticide relatively to the control. The testes weight, libido, serum level of testosterone, mobility, sperm count and the percentage of spermatozoa with entire plasma membrane decreased significantly in animals exposed to cypermethrin with reference to controls. The percentages of abnormal spermatozoa increased significantly in animals submitted to 137.5 or $275 \mathrm{mg} / \mathrm{kg}$ body weight (bw) of cypermethrin compared to control ones. On the testis histological sections of pesticidetreated animals, immature germinal cells were observed in the lumen of seminiferous tubules. Cypermethrin was toxic in male guinea pig and damaged reproductive parameters.
\end{abstract}

DOI: https://doi.org/10.24925/turjaf.v6i2.130-135.1408

\section{Introduction}

Pesticides are widely used in agriculture and veterinary medicine to increase yields (Prasanthi and Rajini, 2005). Cypermethrin is a synthetic class II pyrethrinoid, a large spectrum action insecticide (Singh et al., 2012). It is broadly used in many countries among which Cameroon, because of its efficacy at low doses. Cypermethrin is intensely and globally employed to control a large variety of pests in agriculture and some human and domestic animals ectoparasites (Raina et al., 2010; Mignini et al., 2013; Sparks, 2013; Madhubanti et al., 2014). In spite of these beneficial roles of cypermethrin, its excessive and non controlled use affects non target organisms (Singh et al., 2012). Since cypermethrin is used for pre and post-harvest treatment of many crops (maize, wheat, millet, sorghum...), products and some residues of crops treated with it are used to feed many farm animal species such as guinea pigs, rabbits, grass cutter, goats, sheeps etc. Hence, these animals are exposed to cypermethrin residues contained in ingested feed. Many studies have shown the chronic toxicity of cypermethrin in some mammals (Nair et al., 2011;
Bhushan et al., 2013; EL-Shemi et al., 2015). Nevertheless, to our knowledge, studies showing effects of cypermethrin on the reproduction of farm animals are very scarce, though many of them are necessary to better appreciate the reproductive toxicity of this insecticide used worldwide. The present work aimed to evaluate the toxic effects and reproductive parameters impairment of cypermethrin in male guinea pigs.

\section{Material and Methods}

\section{Animals, Lodging, Feeding and Pesticide}

Forty adult male guinea-pigs (Cavia porcellus) raised at Dschang university teaching and research farm were used. Their mean weight was $387.27 \pm 19.21 \mathrm{~g}$ at the start of the assay. They were identified at the ear and housed in identical cages of $100 \mathrm{~cm} \times 80 \mathrm{~cm} \times 60 \mathrm{~cm}$ (length, width and height) under standard conditions with 12 hours photoperiod and had free access to water and food. They were handled according to ethical guidelines of the Cameroon National Veterinary Laboratory. 
Animals were fed with elephant grass-based ration and a supplement of provender diet.

The pesticide used was cypermethrin $36 \%(360 \mathrm{~g} / \mathrm{L})$, commercially called Cigogne. It was obtained from Louis Dreyfus Commodities Cameroon.

Assay

The animals were distributed into 4 groups of 10 animals each, comparable in body weight. Each group was orally given one of the 4 doses of cypermethrin $(0$, $92,137.50$ and $275 \mathrm{mg} / \mathrm{kg} \mathrm{bw}$ ) for 90 days; group 1 being the control animals received distilled water. The animal body weight was recorded weekly and the doses of pesticide adjusted accordingly.

\section{Collection of Blood and Organs}

Twenty four hours after the last administration of the pesticide solutions, animals were anesthetised using ether vapour and blood was collected by cardiac puncture and used to obtain the serum for the determination of testosterone and other biochemical parameters. After sacrifice, organs such as the testes, epididymis, vas deferens, vesicular glands and prostate, liver and kidneys were collected.

\section{Data Collection}

Sexual desire (libido): The libido was expressed as the reaction time of the male in the presence of a female; on the $90^{\text {th }}$ day of the assay and before sacrifice, each experimental animal was housed with an adult female, and the time taken for the male to chase, sniff the anogenital region of the female or attempt to mount was noted. The maximum observation time for any possible reaction of male in the presence of female was 5 minutes.

Organs weights and volumes: The testes, epididymis, vas deferens, vesicular glands and prostate, liver and kidneys were weighed using a scale of $160 \mathrm{~g}$ capacity and $10^{-3} \mathrm{~g}$ precision. Volumes of testes, kidneys and liver were determined by their immersion in $0.9 \% \mathrm{NaCl}$ solution contained in a graduated cylinder and any displacement of the solution was read.

Testosterone and biochemical parameters concentrations: Testosterone and biochemical parameters (creatinine, urea, aspartate aminotransferase (ASAT), alanine aminotransferase (ALAT), total protein, total cholesterol, bilirubine and phosphatase acid) were quantified in the serum using Omega Diagnostics kit (Scotland, United Kingdom) and CHRONOLAB kits (Barcelona, Spain) respectively.

Sperm characteristics: Animal sperm mobility was evaluated by mincing epididymis tails in a petri dish containing $0.9 \% \mathrm{NaCl}$ solution at $37^{\circ} \mathrm{C}$ and the obtained preparation was observed with light microscope at $400 \mathrm{x}$ magnification. The sperm count was determined using a haemocytometer, while sperm morphological abnormalities (small and big heads, tails winding) and the integrity of the plasma membrane were determined using an eosin-nigrosin solution and the hypo-osmotic test respectively.

Testis structure: The left testis of each animal was fixed in Bouin's fluid, and then washed, dehydrated in alcohol bath of ascending grade, clarified in xylen immersion, embedded in paraffin, sectioned at $5 \mu \mathrm{m}$ and stained with haematoxylin and eosin. The tissue sections were observed under a light microscope at $400 \mathrm{x}$ magnifications.

\section{Statistical Analysis}

Results were expressed as mean \pm standard deviation. Differences between groups were assessed using one way ANOVA followed by the Duncan's test at $5 \%$ significance.

\section{Results}

Weights and Volumes of Kidneys and Liver

In animals exposed to cypermethrin, the weight of kidneys (Table 1) decreased significantly $(\mathrm{P}<0.05)$, whereas that of the liver increased significantly $(\mathrm{P}<0.05)$ with respect to controls.

The volume of kidneys (table 1) was not affected, no matter the dose of administered cypermethrin, while that of the liver significantly $(\mathrm{P}<0.05)$ increased in male treated with $275 \mathrm{mg} / \mathrm{kg}$ bw of cypermethrin compared to controls.

\section{Biochemical Parameters}

Table 2 presents the effects of cypermethrin on some biochemical parameters in male guinea pig. The serum concentration of creatinine, urea, total and direct bilirubine, alanine aminotransferase (ALAT), aspartate aminotransferase (ASAT), total cholesterol, total and prostatic acid phosphatase increased significantly $(\mathrm{P}<0.05)$ in cypermethrin-treated groups relatively to the control. The level of serum total protein and testicular total cholesterol decreased not significantly $(\mathrm{P}>0.05)$ in animals given cypermethrin with reference to controls, while the decrease in the level of testicular total protein was significant $(\mathrm{P}<0.05)$ in treated as compared to control guinea pigs.

Reaction Time (Libido) and Serum Concentration of Testosterone

The time of reaction of male guinea pigs in the presence of females (Figure 1) increased significantly $(\mathrm{P}<0.05)$ when exposed to cypermethrin compared to animals given distilled water. The serum level of testosterone (Figure 2 ) decreased significantly $(\mathrm{P}<0.05)$ in cypermethrin-treated animals in relation to controls.

\section{Weight of Sexual Organs}

The relative weight of epididymis, vas deferens, seminal vesicle and prostate (Table 3) were comparable $(\mathrm{P}>0.05)$ between cypermethrin administered animals and controls. Meanwhile, the weight of testes decreased significantly $(\mathrm{P}<0.05)$ in treated males with respect to controls.

\section{Characteristics of Caudal Epididymis Sperm}

The mobility, numbers of spermatozoa per tails and per gram of epididymis tails, and the percentage of spermatozoa with entire plasma membrane (Table 4) decreased significantly $(\mathrm{P}<0.05)$ in animals exposed to cypermethrin relatively to the control group. The percentages of abnormal spermatozoa increased with increasing dose of cypermethrin, but only animals submitted to 137.5 or $275 \mathrm{mg} / \mathrm{kg}$ bw showed a significant $(\mathrm{P}<0.05)$ difference when compared to controls. 
Table 1 Effects of cyperméthrin on the weights and volumes of kidneys and liver in male guinea pig

\begin{tabular}{|c|c|c|c|c|c|}
\hline \multirow{2}{*}{$\begin{array}{l}\text { Weights and volumes of kidneys and } \\
\text { liver }\end{array}$} & \multicolumn{4}{|c|}{ Dose of cypermethrin (mg/kg bw) } & \multirow{2}{*}{$\mathrm{P}$} \\
\hline & $0(n=6)$ & $92(n=6)$ & $137.5(n=6)$ & $275(n=6)$ & \\
\hline \multicolumn{6}{|l|}{ Weights $(\mathrm{g} / 100 \mathrm{~g} \mathrm{bw})$} \\
\hline Kidneys & $0.71 \pm 0.04^{\mathrm{a}}$ & $0.65 \pm 0.06^{\mathrm{b}}$ & $0.67 \pm 0.05^{\mathrm{ab}}$ & $0.64 \pm 0.03^{\mathrm{b}}$ & 0.04 \\
\hline Liver & $2.49 \pm 0.18^{\mathrm{b}}$ & $2.80 \pm 0.23^{\mathrm{a}}$ & $2.95 \pm 0.15^{\mathrm{a}}$ & $3.04 \pm 0.37^{\mathrm{a}}$ & 0.00 \\
\hline \multicolumn{6}{|l|}{ Volumes (ml) } \\
\hline Kidneys & $3.76 \pm 0.43$ & $3.63 \pm 0.37$ & $3.50 \pm 0.42$ & $3.50 \pm 0.37$ & 0.51 \\
\hline Liver & $12.09 \pm 0.79^{\mathrm{b}}$ & $13.18 \pm 1.28^{\mathrm{ab}}$ & $13.35 \pm 1.23^{\mathrm{ab}}$ & $14.43 \pm 2.47^{\mathrm{a}}$ & 0.04 \\
\hline
\end{tabular}

a, b, c: within the same line, values with the same letters are not significantly (P>0.05) different. n: Number of observations. bw: body weight.

Table 2 Effects of cypermethrin on some biochemical parameters in male guinea pig

\begin{tabular}{|c|c|c|c|c|c|}
\hline \multirow{2}{*}{ Biochemical parameters } & \multicolumn{4}{|c|}{ Dose of cypermethrin (mg/kg bw) } & \multirow{2}{*}{$\mathrm{P}$} \\
\hline & $0(n=6)$ & $92(n=6)$ & $137.5(n=6)$ & $275(n=6)$ & \\
\hline Creatinine (mg/dl) & $0.10 \pm 0.06^{\mathrm{b}}$ & $0.48 \pm 0.05^{\mathrm{a}}$ & $0.44 \pm 0.09^{\mathrm{a}}$ & $0.42 \pm 0.05^{\mathrm{a}}$ & 0.00 \\
\hline Urea $(\mathrm{mg} / \mathrm{dl})$ & $85.71 \pm 21.48^{c}$ & $169.64 \pm 31.26^{\mathrm{a}}$ & $114.29 \pm 24.87^{\mathrm{bc}}$ & $151.79 \pm 32.16^{\mathrm{ab}}$ & 0.00 \\
\hline Total bili (mg/dl) & $1.79 \pm 0.24^{\mathrm{b}}$ & $1.96 \pm 0.26^{\mathrm{ab}}$ & $2.02 \pm 0.31^{\mathrm{ab}}$ & $2.22 \pm 0.35^{\mathrm{a}}$ & 0.04 \\
\hline Direct bili (mg/dl) & $0.71 \pm 0.09^{c}$ & $0.90 \pm 0.10^{\mathrm{b}}$ & $0.98 \pm 0.09^{b}$ & $1.26 \pm 0.18^{\mathrm{a}}$ & 0.00 \\
\hline ALAT (IU) & $18.95 \pm 2.79^{\mathrm{b}}$ & $21.06 \pm 3.85^{\mathrm{b}}$ & $29.93 \pm 2.32^{\mathrm{a}}$ & $30.63 \pm 1.81^{\mathrm{a}}$ & 0.00 \\
\hline ASAT (IU) & $17.95 \pm 1.35^{\mathrm{c}}$ & $23.45 \pm 2.85^{\mathrm{b}}$ & $38.73 \pm 3.15^{\mathrm{a}}$ & $40.48 \pm 1.90^{\mathrm{a}}$ & 0.00 \\
\hline Serum total protein $(\mathrm{g} / \mathrm{dl})$ & $3.29 \pm 0.60$ & $2.64 \pm 0.54$ & $2.50 \pm 0.66$ & $2.50 \pm 0.43$ & 0.12 \\
\hline Serum total cholesterol $(\mathrm{mg} / \mathrm{dl})$ & $11.37 \pm 1.27^{\mathrm{c}}$ & $15.99 \pm 3.08^{\mathrm{b}}$ & $16.12 \pm 3.02^{\mathrm{b}}$ & $19.82 \pm 2.50^{\mathrm{a}}$ & 0.00 \\
\hline Testicular total protein $(\mathrm{g} / \mathrm{dl})$ & $1.81 \pm 0.33^{\mathrm{a}}$ & $0.92 \pm 0.34^{c}$ & $0.90 \pm 0.11^{\mathrm{c}}$ & $1.34 \pm 0.18^{\mathrm{b}}$ & 0.00 \\
\hline Testicular total cholesterol (mg/dl) & $0.86 \pm 0.13$ & $0.73 \pm 0.13$ & $0.75 \pm 0.13$ & $0.66 \pm 0.21$ & 0.34 \\
\hline Total acid phosphatase (U/l) & $1.47 \pm 0.26^{\mathrm{b}}$ & $2.29 \pm 0.16^{\mathrm{a}}$ & $2.41 \pm 0.36^{\mathrm{a}}$ & $2.66 \pm 0.22^{\mathrm{a}}$ & 0.00 \\
\hline Prostatic acid phosphatase (U/1) & $0.54 \pm 0.19^{\mathrm{b}}$ & $1.15 \pm 0.16^{\mathrm{a}}$ & $1.04 \pm 0.29^{\mathrm{a}}$ & $1.34 \pm 0.16^{\mathrm{a}}$ & 0.00 \\
\hline
\end{tabular}

$\mathrm{a}, \mathrm{b}, \mathrm{c}$ : within the same line, values with the same letters are not significantly $(\mathrm{P}>0.05)$ different. n: number of observations. bw: body weight. Bili: bilirubin

Table 3 Effects of cypermethrin on the weight of genital organs in male guinea pig

\begin{tabular}{|c|c|c|c|c|c|}
\hline \multirow{2}{*}{$\begin{array}{l}\text { Weight of genital organs } \\
(\mathrm{g} / 100 \mathrm{~g} \mathrm{bw})\end{array}$} & \multicolumn{4}{|c|}{ Dose of cypermethrin (mg/kg bw) } & \multirow{2}{*}{$\mathrm{P}$} \\
\hline & $0(n=6)$ & $92(n=6)$ & $137.5(n=6)$ & $275(n=6)$ & \\
\hline Testes & $0.54 \pm 0.03^{\mathrm{a}}$ & $0.44 \pm 0.02^{\mathrm{b}}$ & $0.46 \pm 0.02^{\mathrm{b}}$ & $0.43 \pm 0.05^{\mathrm{b}}$ & 0.00 \\
\hline Epididymis & $0.11 \pm 0.01$ & $0.11 \pm 0.02$ & $0.11 \pm 0.01$ & $0.11 \pm 0.02$ & 0.79 \\
\hline Vas deferens & $0.05 \pm 0.01$ & $0.06 \pm 0.02$ & $0.06 \pm 0.01$ & $0.06 \pm 0.01$ & 0.36 \\
\hline Seminal vesicle and prostate & $0.53 \pm 0.04$ & $0.46 \pm 0.10$ & $0.46 \pm 0.11$ & $0.47 \pm 0.09$ & 0.52 \\
\hline
\end{tabular}

$\mathrm{a}, \mathrm{b}, \mathrm{c}$ : within the same line, values with the same letters are not significantly $(\mathrm{P}>0.05)$ different. $\mathrm{n}$ : Number of observations. bw: body weight.

Table 4 Effects of cypermethrin on caudal epididymal sperm characteristics in male guinea pig

\begin{tabular}{|c|c|c|c|c|c|}
\hline \multirow{2}{*}{$\begin{array}{l}\text { Caudal epididymis sperm } \\
\text { characteristics }\end{array}$} & \multicolumn{4}{|c|}{ Dose of cypermethrin (mg/kg bw) } & \multirow{2}{*}{$\mathrm{P}$} \\
\hline & $0(n=6)$ & $92(n=6)$ & $137.5(n=6)$ & $275(n=6)$ & \\
\hline Mobility (\%) & $88.75 \pm 6.41^{\mathrm{a}}$ & $67.50 \pm 8.86^{\mathrm{b}}$ & $63.75 \pm 9.16^{\mathrm{b}}$ & $66.25 \pm 7.44^{\mathrm{b}}$ & 0.00 \\
\hline Number/tail of epididymis (x $10^{6}$ ) & $270.00 \pm 74.09^{\mathrm{a}}$ & $207.22 \pm 51.91^{\mathrm{ab}}$ & $186.11 \pm 86.02^{b}$ & $191.11 \pm 74.03^{\mathrm{b}}$ & 0.04 \\
\hline Number/g of epididymal tail (x $\left.10^{6}\right)$ & $498.31 \pm 98.33^{\mathrm{a}}$ & $391.57 \pm 84.10^{\mathrm{b}}$ & $356.01 \pm 82.32^{\mathrm{b}}$ & $369.87 \pm 63.69^{\mathrm{b}}$ & 0.02 \\
\hline IPM of spermatozoa $(\%)$ & $91.00 \pm 5.45^{\mathrm{a}}$ & $78.71 \pm 6.75^{b}$ & $76.57 \pm 5.74^{\mathrm{b}}$ & $68.71 \pm 5.12^{\mathrm{c}}$ & 0.00 \\
\hline Spermatozoa with small and big heads (\%) & $8.63 \pm 1.99^{c}$ & $11.11 \pm 2.76^{\mathrm{c}}$ & $19.14 \pm 3.53^{b}$ & $23.43 \pm 5.06^{\mathrm{a}}$ & 0.00 \\
\hline Spermatozoa with coiled tails $(\%)$ & $1.88 \pm 0.84^{\mathrm{c}}$ & $2.20 \pm 0.45^{\mathrm{c}}$ & $3.44 \pm 0.88^{\mathrm{b}}$ & $5.88 \pm 0.99^{\mathrm{a}}$ & 0.00 \\
\hline
\end{tabular}

a, b, c: within the same line, values with the same letters are not significantly ( $>0.05)$ different. $n$ : Number of observations. bw: body weight. IPM: integrity of the plasma membrane.

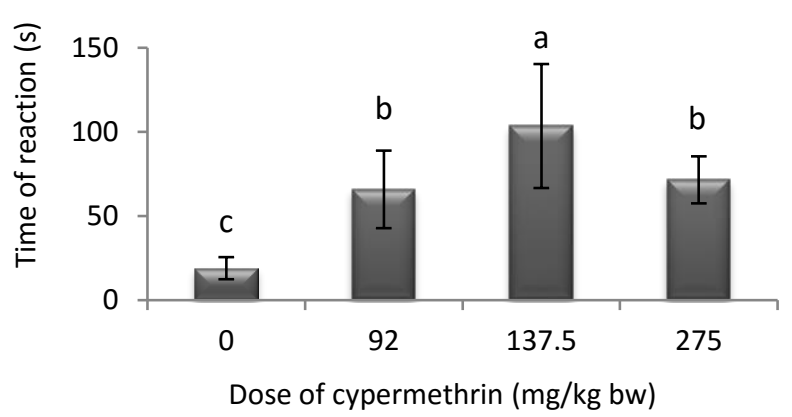

Figure 1 Effects of cypermethrin on the time of reaction (libido) in male guinea pig

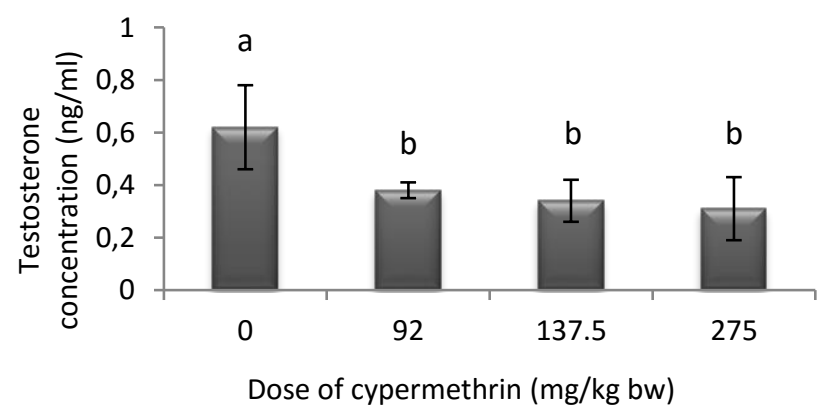

Figure 2 Effects of cypermethrin on serum testosterone concentration in male guinea pig 

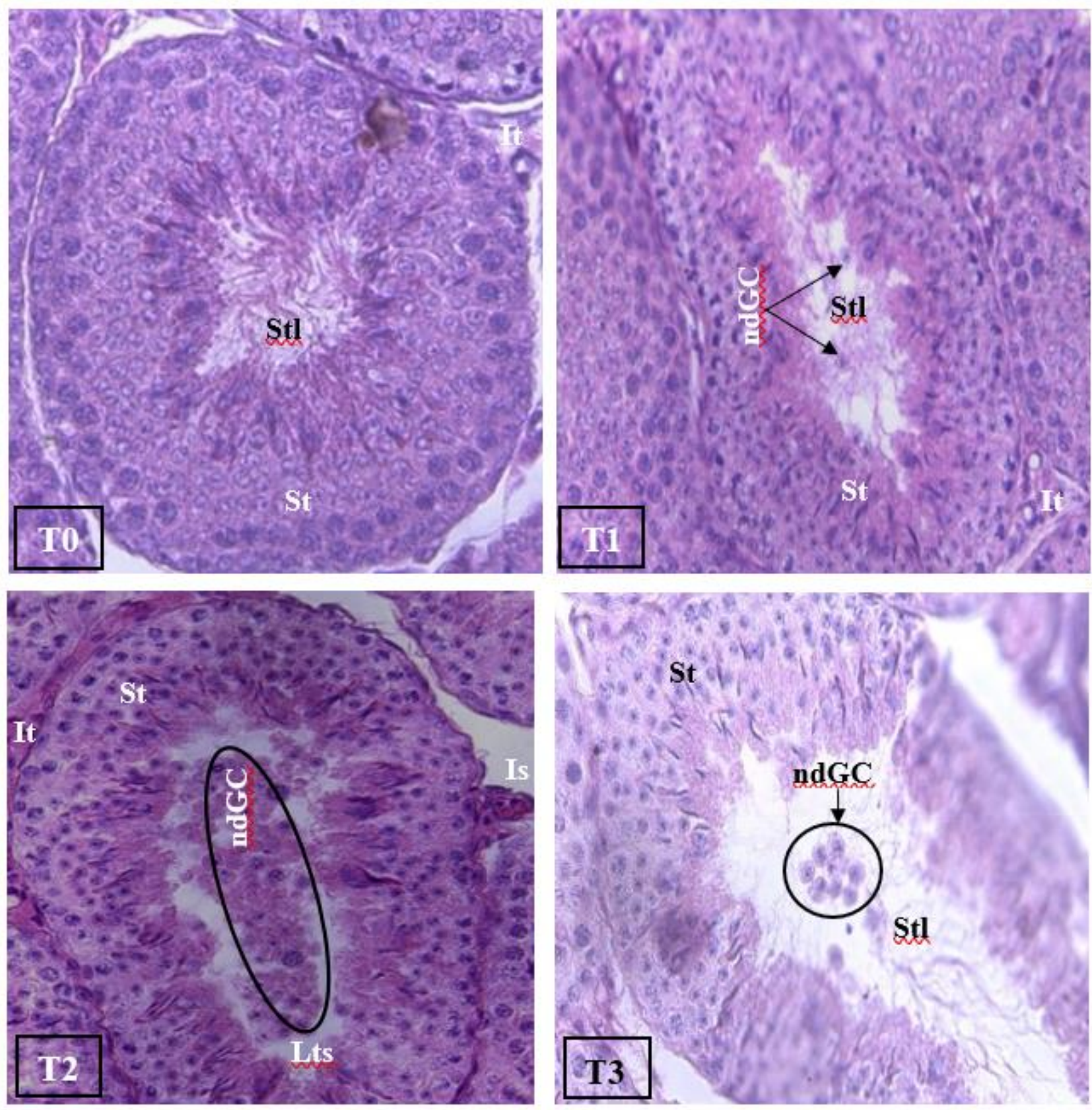

Figure 3 Histological sections of testis in male guinea pig exposed to cypermethrin (HE x 400)

ndGC: non differentiated germinal cells; Is: interstitial space; Stl: seminiferous tubule lumen; It: interstitial tissue; St: seminiferous tubule; BV: blood vessel. T0-: control 1 (distilled water); T1, T2 and T3: 92, 137.5 and $275 \mathrm{mg} / \mathrm{kg}$ bw of cypermethrin respectively

\section{Testis Structure}

The histological structures of the testis of male guinea pig exposed to cypermethrin are illustrated by the Figure 3. A typical structure of the testis was observed in controls; the seminiferous epithelium contained all generations of germinal cells corresponding to the stages of seminiferous epithelium cycle; the lumen contained normal flagellated spermatozoa. In cypermethrin-treated animals, the lumen contained non differentiated germinal cells.

\section{Discussion}

The evaluation of detoxifying organs weight is of a great importance for the appreciation of the toxic potential of a substance (Oloyede et al., 2011). The liver plays an essential role in the metabolism and detoxification of pesticides (Mossa et al., 2015). The significant increase of the liver weight in cypermethrin treated guinea pigs in this study is similar to that reported by Mossa et al. (2015) in mice treated with cypermethrin $(13.8 \mathrm{mg} / \mathrm{kg}$ bw). But it is contrary to observations of Li et al. (2013) in rats submitted to cypermethrin $(7.5,15,30$ and 60 $\mathrm{mg} / \mathrm{kg} \mathrm{bw}$ ). This increase of the liver weight could be due to the intensive activity of detoxification carried out by this organ (Kadota et al., 1976). The decrease of the kidneys weight in the current study is similar to that observed by Rezzag and Serouti (2015) in rabbits exposed to metribuzine and contradictory to that obtained by Djeffal (2014) in rats submitted to methomyl. In the present work, the histological structure of the kidney was not examined, but it is probable that the cypermethrin treatment had induced an alteration of the kidney structure, and then the decrease of its weight. Hence, the 
increase in the serum level of urea and creatinine could be a consequence of a structural and functional disturbance of the kidney, since they are filtered at its level.

The attack of the liver and kidneys can be more appreciated by evaluating biochemical parameters (Kalender et al., 2005). The rise in ALAT and ASAT levels as shown by many other studies on pesticides (Madkour, 2012; Ibiang et al., 2013; Djeffal, 2014; ElShemi et al., 2015) might be due to the intensification of the secretory activity of the liver (Yousef et al., 1999). It could also be explained by the alteration of the plasma membrane permeability or by hepatic necrosis, leading to the escape of tissue enzymes into plasma (El-Demerdash et al., 2012). That hepatic dysfunction could be the cause of the increase in cholesterol and bilirubun concentrations, since they are eliminated at its level.

The rates of creatinine and urea are indicators of the conditions and functioning of kidneys. The increase of their level in this study could show the toxicity of cypermethrin on the kidneys. Pesticides like malathion (Ismail, 2013), methomyl (Djeffal, 2014), metribuzin and mancozeb (Chiali, 2014) induced the similar results. This could be the result of the reduced capacity of the kidneys to filter and eliminate these substances from blood into urines. It could also be due to an increase in protein catabolism following the high stimulation by the insecticide of the synthesis of the enzyme arginase, which intervenes in the production of urea (Yanardag and Sacan, 2007). In fact, a decrease in the level of protein was observed in this study and this could be due to their high degradation for metabolic needs.

Phosphatases are critical enzymes in the biological system, responsible for the metabolism and the detoxification of toxic substances and the biosynthesis of energetic macromolecules. Their interference with toxic substances leads to biochemical disruption, lesions of tissues and loss of the cellular function (Djeffal, 2014). Prostatic acid phosphatase is a biomarker of a testicular dysfunction (El-Tohamy and El-Nattat, 2010). The increase of their activity in the serum might be due to the rise of the plasma membrane permeability (Rahman et al., 2000).

The decrease in the weight of testes in insecticidetreated guinea pigs noticed in this study was previously observed by Li et al. (2013) and Madhubanti et al. (2014) in rats, using the same pesticide. The diminution in the testicular weight could be explained by the fact that the insecticide had induced the alteration of the testicular structure. The presence of immature germinal cells in the seminiferous tubule lumen of guinea pigs exposed to cypermethrin might be a consequence of an exfoliation of non differentiated germinal cells, which could have then affected the weight of testes.

The decrease in the serum concentration of testosterone in pesticide administered groups was predictable, because there is a positive relationship between the testicular development and the testosterone production. Since the libido and spermatogenesis are under the control of testosterone, the lower libido in treated groups, expressed here by their long time of reaction in the presence females and the reduction in the epididymal sperm quality could be a consequence of the decrease in testosterone concentration in the blood.

\section{Conclusion}

Cypermethrin was toxic to male guinea pig after 90 days of treatment. For genital organ weights, only the weight of testes was affected. The epididymal sperm characteristics, libido and serum level of testosterone were seriously impaired.

\section{References}

Bhushan B, Pande S, Saxena N and Saxena PN. 2013. Serum biochemical responses under stress of cypermethrin in albino rat. Environ Exp Biol, 11: 81-89.

Chiali FZ. 2014. Effets métaboliques d'un régime à base de purée de pomme de terre contaminée par les pesticides chez le rat wistar. Thèse de Doctorat en Physiologie et Biochimie de la Nutrition. Université Abou Bekr Belkaid Tlemcen, Algérie, 205 p.

Djeffal A. 2014. Evaluation de la toxicité d'un insecticide carbamate « méthomyl » chez le rat Wistar : Stress oxydant et exploration des effets protecteurs de la supplémentation en sélénium et/ou en vitamine $\mathrm{C}$. Thèse de Doctorat en Biochimie. Université Badji Mokhtar-Annaba, Algérie, 225p.

El-Demerdash FM, Attia AA, Elmazoudy RH. 2012. Biochemical and histopathological changes induced by different time intervals of methomyl treatment in mice liver. J Environ Sci Health, 47(12): 1948-1954.

El-Shemi AG and El-Ella GAA. 2015. Hepatic and neural toxicity and tissue residue of cypermethrin male Somalian sheep (Berbera blackhead). Assiut Vet Med J, 61: 52-59.

El-Tohamy MM, El-Nattat WS. 2010. Effect of antioxidant on leadinduced oxidative damage and reproductive dysfunction in male rabbits. J Am Sci, 6(11): 613-622.

Ibiang YB, Ekaluo UB, Nta AI, Ikpeme EV, Ekanem BE, Erem FA. 2013. Effect of deltamethrin and ridomil on serum biochemical parameters in the rat (Rattus norvegicus). Eur J Toxicol Sci, 5: $1-13$.

Ismail SM. 2013. Protective effects of vitamin $\mathrm{C}$ against biochemical toxicity induced by malathion pesticides in male albino rat. J Evol Biol Res, 5(1): 1-5.

Kadota T, Okuna Kohdo H and Mtyamoto J. 1976. Mammalians toxicological study of permethin, 3 phenoxy benzyl $( \pm)$ astrans2, 2- dimethyl-3-(2, 2 dichlorvinyl)-cyclopropane-1carboxylate. Botyukgoku, 41: 143-151.

Kalender S, Ogutcu A, Uzunhisarcikly M, Acikgoz F, Durak D, Ulusoy Y and Kalender Y. 2005. Diazinon induced hepatotoxicity and protective effect of vitamin $\mathrm{E}$ on some biochemical indices and ultrastructural changes. Toxicology, 211: 197-206.

Li YF, Pan C, Hu JX, Li ., Xu LC. 2013. Effects of cypermethrin on male reproductive system in adult rats. Biomed Environ Sci, 26(3): 201-208.

Madhubanti B, Pralay M, Tuhina D and Sujata MC. 2014. Zinc and alpha-lipoic acid alleviate cypermethrin induced reproductive toxicity in mature male wistar rat. Int j life sci pharma res, 4(2): 9-20

Madkour NK. 2012. Protective effect of curcumin on oxidative stress and DNA fragmentation against lambda cyhalothrininduced liver damage in rats. J appl pharm sci, 2(12): 076-081.

Mignini F, Nasuti C, Fedeli D, Mattioli L, Cosenza M, Artico M, Gabbianelli R. 2013. Protective effect of alpha-lipoic acid on cypermethrin-induced oxidative stress in wistar rats. Int $\mathbf{J}$ Immunopathol Pharmacol, 26(4): 871-881.

Mossa AH, Heikal TM, Belaiba M, Raoelison EG, Ferhout H, Bouajila J. 2015. Antioxidant activity and hepatoprotective potential of Cedrelopsis grevei on cypermethrin induced oxidative stress and liver damage in male mice. BMC Complement Altern Med, 15(251): 1-10.

Nair RR, Abraham MJ, Lalithakunjamma CR, Nair ND and Aravindakshan CM. 2011. A pathomorphological study of the sub lethal toxicity of cypermethrin in Sprague Dawley rats. Int J Nutr Pharmacol Neurol Dis, 1: 179-183. 
Oloyede A, Okpuzor J, Omidiji O, Odeigah P. 2011. Evaluation of sub-chronic oral toxicity of joloo: a traditional medicinal decoction. Pharm Biol, 49: 936-941.

Prasanthi KM and Rajini PS. 2005. Morphological and biochemical changes in rat erythrocytes after administration of lambda cyhalothrin. Toxicol In Vitro, 19: 449-456.

Rahman MF, Siddiqui MK, Jamil K. 2000. Acid and alkaline phosphatase activities in a novel phosphorothionate (RPR-11) treated male and female rats. Evidence of dose and time dependent response. Drug Chem Toxicol, 23: 497-509

Raina R, Verma PK, Pankaj NK, Kant V, Prawez S. 2010 Protective role of L-ascorbic acid against cypermethrin-induced oxidative stress and lipid peroxidation in Wistar rats. Toxicol Environ Chem, 92(5): 947-953.

Rezzag MOS et Serouti A. 2015. Contribution à l'étude de l'effet de la métribuzine sur la cytotoxicité et la reproduction chez les lapines (Oryctolagus cuniculus). Thèse de Master en Sciences de la Nature et de la Vie. Université Echahid Hamma Lakhdar, Algérie, 92p.
Saitoh MT, Yanase H, Morinaga MT and Mu YM. 2001. Tributyltin or triphenyltin inhibits aromatase activity in the human granulosa-like tumor cell line KGN. Biochem Biophys Res Commun, 289: 198-204.

Singh AK, Tiwari MN, Prakash O, Singh MP. 2012. A current review of cypermethrin-induced neurotoxicity and nigrostriatal dopaminergic neurodegeneration. Curr Neuropharmacol, 10: 64-71.

Sparks TC. 2013. Insecticide discovery: An evaluation and analysis. Pestic Biochem Physiol, 107: 8-17.

Yanardag R and Sacan OO. 2007. Combined effects of vitamin C, vitamin $\mathrm{E}$, and sodium selenite supplementation on absolute ethanol induced injury in various organs of rats. Int J Toxicol, 26(6): 513-523.

Yousef MI, Abbassi MS and Yacout MHM. 1999. Assessment of cypermethrin and dimethoatetoxicity in Barkysheep. Biochemical and histological changes and tissue residues. Egyptian J Anim Prod, 36: 25-41. 